\title{
EDUCATIONAL EMPLOYEE HIGH PERFORMANCE WORK PRACTICES: A FOURTH INDUSTRIAL CONTEXT
}

\author{
Taha Shabbir \\ Department of ASCE, \\ University of Karachi, \\ Sindh, Pakistan \\ Email: tahashabbir51@gmail.com \\ M. Nadeemullah \\ Associate Professor, \\ Social Work Department, University of Karachi \\ Sindh, Pakistan \\ Email: nadeemullah@uok.edu.pk
}

\begin{abstract}
The study examines the relationship of high-performance work practices (training, empowerment and rewards) with employee performance in the context of the fourth industrial revolution in private university settings. To get the desired result, a crosssectional sample of 334 male and female educational employees will write their responses using questionnaires. Structural equation modelling is used for computation. The managers have to cater to the revolutions taking place, and they have to develop standard operating procedures for working in private universities. The managers have to rethink high-performance work practices being used in organizations to achieve better performance. Training regarding using organizational resources may also be considered as a remedy. They are using organizational resources and time appropriately with developing trust among the employer and employees, thus fostering performance. The results show a weak relationship between the selected high-performance work practices with educational employee performance. Empowerment is having a negative connection with the performance that nullifies the existing evidence.
\end{abstract}

\section{KEYWORDS}

High performance work practices, training, empowerment, rewards, fourth industrial revolution, Universities, Pakistan, Education

\section{INTRODUCTION}

A paradigm (physical world to a virtual world) shift is observed in the recent past, 
called as, fourth industrial revolution or industry 4.0. It is the technological advancement affecting every aspect of the organization including human resource management (Pandian, 2018) by using robotics, artificial intelligence, and so forth for reducing failures.

Fourth industrial revolution has brought with it multiple avenues to provide services and has introduced the concept of boundary-less organizations. The boundary less organizations has at the same time provided access to reach broader range of people and compelled individuals to earn more and more. Although, it is in its infancy, in Pakistan, but has effected several aspects of the organization (Wilkesmann, \& Wilkesmann, 2018). Moreover they argued that it allows the human beings to fill in the gaps that machines cannot handle.

Bamber, Bartram, and Stanton (2017) argued that educational employee met with new challenges when it comes to fourth industrial context. As there is more advancement is science and technology and also there is a integration of different fields when it comes to educational course, the employee too faces new challenges. (Bamber, Bartram, \& Stanton, 2017). On the recommendations of them the current study is conducted.

Moreover, it is argued that on one side the organizations are becoming mechanized and prefer to use technology for better management and on the other side the people are getting smarter to manage multiple tasks and try to tap multiple opportunities simultaneously, contributing towards their financial stability. At the same time this multi-tasking disrupts their attention towards primary job and there are chances of disrupted employee performance at the primary workplace. During at work place the performance of employee is judged according to the quality of work he/she delivered specifically on certain period of time (Pawirosumarto, Sarjana, \& Muchtar, 2017; Rivai, 2004). In this regard the organizations are trying hard to maintain and sustain the higher levels of employee's performance (Garg, 2019). The required levels of performance are necessary for better organizational outcomes (Shin, \& Konrad, 2017). Organizations try making an environment to support employee performance (Anitha, 2014) but the factors prevailing in the internal and external environment make things different (Murphy, Torres, Ingram, \& Hutchinson, 2018).

As a part of enhancing employee outcomes the organizations have adopted the concept of high-performance work practices (HPWP), which are comprise of certain set of rules and are restricted to high authorities at work place, practice and performance (Posthuma et al., 2013). The employee dedication and quality of work can be judged by observing certain HR practices.(Mahmood, et al., 2018; Kehoe and Wright, 2013; Posthuma et al., 2013). Further it is noted that HPWP support the improvements in 
employee performance (Shin \& Konrad, 2017). It is noted that HPWP comprise various practices to maximize employee knowledge, commitment and performance (Bohlander and Snell, 2007).

The aim of this research is to observe the effects of three specific high performance work practices (i.e. training, empowerment and rewards) on university employee performance (teacher's performance). Therefore, the research observes the linkage of educational employee and their attitude (Zhang and Morris, 2014) contributing towards performance. The research gives new horizon related to fourth industrial revolution acting in a developing country perspective. The research tells one of the tested in Canada by Fabi et al. (2015), and by Luna-Arocas and Camps (2007), who tested model in France. Using these results we find a bond of similar result to that in Pakistan The same scenario is exist to other under developed Asian countries wherein HR strategies and practices remain under paper written only and can easily be witnessed (Chen et al., 2016; Chadwick et al., 2015; Maharjan and Sekiguchi, 2016). Kim and Choi (2014) found that higher investments in employee capability through various measures bring employer-employee harmony that consequentially enhance performance on the job but have ignored keeping in view the influence of fourth industrial revolution on HR practices and performance that this study addresses particularly.

\section{LITERATURE REVIEW}

\section{Training and employee performance}

Training helps employees equip them with the better ability to do various task. Relevant trainings equip the people in the right direction whereas the irrelevant trainings are sources of wastage of time and resources (Pruneda, 2015). In the universities the teachers need to have trainings related to teaching and behavioral advancements that enhance their performance (Arif \& Ilyas, 2013). Providing training to the employees show a gesture that the employees are ever valuable partners of the organization (Kundu, Kumar \& Gahlawat, 2019) and are sources of gaining sustainability (Takeuchi et al., 2007). Training is regarded as an effective tool to manage people's commitment and in enhancing service quality (Kim et al., 2009). At the same time it has several managerial implications in enhancing employee performance (Karatepe, 2013). Further reduced errors can be ensured through providing training to the employees (Aladwan, Bhanugopan, \& D'Netto, 2015). Thus the hypothesis developed is;

H1: Training has a strong positive link with employee's job performance.

\section{Empowerment and employee performance}

Quality performance can be ensured through empowering employees and giving them the appropriate resources (Sattar, Ahmad \& Hassan, 2015). More recently, Kundu, 
Kumar and Gahlawat (2019) found employee empowerment positively and significantly related to employee performance. When the employees are given the powers and responsibilities, and they are encouraged to participate in decision making. This enrich them with the confidence and freedom to perform in their own way without direct involvement of the management, thus leaving them to use power and resources as and when they require (Awamleh, 2013; Hong, Tan, \& Bujang, 2010).

It is also noted that the knowledge explosion, as a result of fourth industrial revolution, also known as information and communication technology revolution (Hsu \& Sabherwal, 2012; Kasasbeh. 2015) has empowered employees to get better outreach and making it a challenge for the organization (Krylova et al., 2016) to retain and sustain the HR.

Moreover, delegation of authority is the important part of the empowerment by using which the employees perform duties, but at the same time it is to keep in mind that the performers should be made accountable for their actions (Al-Jammal et al., 2015) otherwise they may show undesirable performance. Thus the hypothesis developed of examination is;

H2: Employee empowerment has a strong positive relationship with employee performance.

\section{Rewards and employee performance}

Organizations offer their employees the monetary and non-monetary rewards as a result of the efforts done by them. Motivating the pool of HR possessed by the organization is the main reason behind (Liu, \& Li, 2017). Rewards are also essential in order to motivate the employee. The psychology says that employee perform much better if they get rewarded of their work. So is true with educational employee which was often ignored in term of rewarding the workers (Allen, \& Kilmann, 2001). Without offer appropriate rewards the high performance cannot be ensured. The rewards have the reciprocal effect on the employees. Employees work for rewards and rewards motivate them to work harder and smarter (Liu, Zhao, \& Xie, 2016). For achieving more rewards the employees get involved in their work and show higher performance. The pay for performance is rightly used as a tool for achieving higher performance standards (Garen, 2016).

Looking at the teacher's perspective, the teachers are generally seen motivated to work for intrinsic and extrinsic rewards available at workplace. The more satisfied the teachers are the better contribution towards students they can make (Liang, \& Akiba, 2015). Thus the hypothesis developed is;

H3: Rewards have a strong positive relationship with employee performance. 


\section{Social Exchange Theory and Fourth Industrial Revolution}

Social Exchange Theory is of the view that there is likelihood that trusting and loyal relationships may develop when the mutual commitments between employees and employer are fulfilled keeping in view their mutual benefits by following certain rules (Cropanzano \& Mitchell, 2005). The relationships between employee and employer are generally built due to economic or social reasons (Karatepe, 2013).

The discussed theory also suggests that it is basically a two sided story. In order to get more from your employee you have to be equally regarded him of his duties and tasks and many often you have to ignore his some mistakes. It can be inferred from the theory that the supportive work environment may compel employees to indulge in activities liked by employees. The fourth industrial revolution brings with it additional avenues that allow employees to jump from inside to outside to use their knowledge, skills and abilities. Thus adding something instead of positive but negative to the employee behaviors as per organizations point of view.

\section{CONCEPTUAL FRAMEWORK}

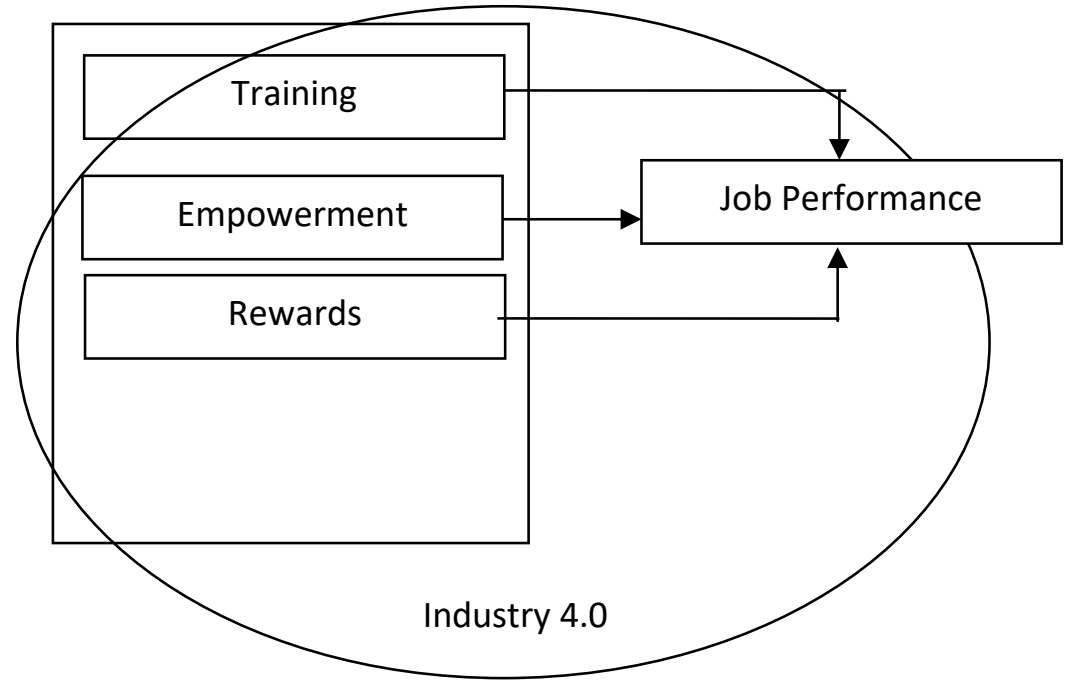

Figure 1. Research framework examining HPWP and Employee Performance.

\section{RESEARCH OBJECTIVES}

1. Examine teaching, learning and Globalization.

2. Assessment of productivity Quality research, equity and excellence.

3. Find out how Globalization has influenced learning process improvement in Nigeria and Pakistan Higher Education.

4. Identify the impact of Globalization in the educational reform revolution, service 
delivery of scholars / research in higher education.

\section{RESEARCH QUESTIONS}

1. How do Education stakeholders understand globalization and its impact on education Globally?

2. Have Education Reforms better positioned Nigeria and Pakistan to respond to opportunities and challenges of Globalization?

3. To what extent does Globalization influence the quality of research / scholarly output in Nigeria and Pakistan?

4. To what extent does Globalization helps in improving learning process in Nigeria and Pakistan Higher Education?

\section{RESEARCH METHODOLOGY}

The sample was drawn from a pool of the full-time working university teachers working in the private sector. The private sector was particularly selected for the reason that does not ensured job security and other security benefits like pension and social security etc. A convenience sample of 334 teachers (male, $n=214$ and female, $n=$ 120) was selected. The private sector universities in Pakistan are characterized with restricted resources (including financial benefits) that may call for looking at other opportunities available to the employees. Twenty private sector universities throughout the country were selected for broader response rate. The universities were having different departments four departments were selected in each university for collecting responses such as engineering, social sciences, computer sciences and management sciences. This provided an edge to collect broader range of responses dealing various aspects of freelancing activities.

Keeping in view the technological advancement with context to industrial revolution, the questionnaire are structured according to the view that employee use technology in a smarter way in order to obtain better work result and to accelerate the working speed. The questionnaire for training, empowerment, rewards and employee job performance were adapted from the study of Karatepe (2013) having statements based on five points Likert type scale. Moreover three questions/statements were asked regarding working for outside people/clients while at work, to which the respondents agreed. The statements used to record responses are provided at the end of the research paper as an appendix.

\section{RESULTS AND DISCUSSIONS}

Structural equation modeling was employed by using SmartPLS software. The measurement model and structural models were reported as a part of results of this study. 


\section{Measurement Model - Convergent Validity}

Convergent validity is examined through factor loadings (outer loadings), composite reliability (CR) and average variance extracted (AVE). These indicate the degree to which multiple items to measure the same concept are in agreement (Hair, Black, \& Babin, 2010). Factor loadings per items should have recommended value of 0.6 or above and it shows internal consistency (Chin, Gopal, \& Salisbury, 1997). The composite Reliability depicts the degree to which the indicators of construct indicate the latent. The cut-off point for this is more than or equal to 0.7 (Hair et al., 2010). The Average Variance Extracted (AVE) shows the overall amount of variance in the indicators accounted for by the latent construct. It should have the recommended value of 0.5 . All the constructs used for this study that are training, empowerment, rewards and employee performance fulfill the criteria, see table 1 .

Table 1

Results of the Measurement Model

\begin{tabular}{lllll}
\hline \hline Construct & Measurement Item & Loading & CR & AVE \\
\hline Training & TR1 & 0.7594 & 0.8940 & 0.6789 \\
& TR2 & 0.8453 & & \\
TR3 & 0.8676 & & \\
TR4 & 0.8152 & & \\
Empowerment & TR6 & 0.8032 & & 0.6278 \\
& ET1 & 0.8096 & & \\
& ET2 & 0.7389 & 0.8707 & \\
& ET3 & 0.8129 & & 0.7085 \\
Rewards & ET4 & 0.8377 & & \\
& ET5 & 0.8373 & & \\
& RW1 & 0.8455 & 0.9067 & \\
& RW2 & 0.8655 & & \\
& RW3 & 0.8687 & & \\
RW4 & 0.7339 & & \\
Emp. Performance & RW5 & 0.7568 & & \\
& EP1 & 0.7038 & 0.8949 & \\
& EP2 & 0.7080 & & \\
& EP3 & 0.7122 & & \\
\hline \hline CR= Compo0site Reliability, AVE= Average Variance Extracted & \\
\hline
\end{tabular}




\section{Discriminant Validity}

As the name says the discriminant validity is used to see the contrast and differences among different measures and variables (Hulland, 1999), for this the square root of the Average Variance Extracted (AVE) and the correlation coefficients are used. The square roots of AVE values are available in the diagonal and the lower value of correlation coefficient than the square root of the AVE indicates "distinct theoretical entities" (Hulland, 1999), see table 2.

Table 2

Discriminant Validity of Constructs

\begin{tabular}{llllll}
\hline Construct & & TR & ET & RW & EP \\
\hline TR & 0.8240 & 0.7923 & & & \\
ET & 0.7914 & 0.7114 & 0.6932 & & \\
RW & 0.4123 & 0.3680 & 0.5486 & 0.8417 & \\
EP & 0.4360 & 0.4231 & 0.5653 & 0.6278 & $\mathbf{0 . 8 5 9 9}$ \\
\hline
\end{tabular}

Diagonals represent the square root of AVE, TR= Training, ET= Empowerment, $\mathrm{RW}=$ Rewards, $\mathrm{EP}=$ Employee Performance.

\section{Structural Model}

To find the relationship among different models a structural model is framed. The 5000 subsample with the help of boot strapping is used (Hair et al., 2012). The significance of path coefficient is obtained by using the t-values (Hair Jr, Sarstedt, Hopkins, \& Kuppelwieser, 2014, McIntosh, Edwards, \& Antonakis, 2014, Sarstedt, Ringle, Smith, Reams, \& Hair Jr, 2014). The value of R Square and path coefficients beta and significance indicates how well the model is supported (Surienty et al., 2013). Table 3 shows the structural model. The training $(\beta=0.4854, p \leq 0.01)$, empowerment $(\beta=0.2977, p \leq 0.01)$, rewards $(\beta=0.1585, p \leq 0.01)$ explaining 0.755 variance that is $75.5 \%$ variance in the employee performance.

Table 3

Summary of the Structural Model

\begin{tabular}{llll}
\hline Path Hypothesis & $\begin{array}{l}\text { Path } \\
\text { Coefficient }=\boldsymbol{\beta}\end{array}$ & t- value & Results \\
& 0.4850 & 13.0342 & Supported \\
\hline TR----->EP & -0.2988 & 2.5093 & Not-Supported \\
ET----->EP & 0.1592 & 4.5670 & Supported \\
RW----->EP & & &
\end{tabular}

The end results show a weak positive relationship (see beta values) of all the selected factors considered for examination such as training, empowerment and rewards with 
employee performance. It can be inferred that the high-performance work practices does not play a significant role in shaping employee performance within the university.

\section{DISCUSSION}

Earlier studies have found strong positive linkages between providing training to employees, empowering them, rewarding them and their performance (Pruneda, 2015; Karatepe, 2013; Kundu, Kumar \& Gahlawat, 2019) in the normal functional contexts. The revolutionary contexts are ignored at large. In the revolutionary contexts the practices are changing at the individual and organizational levels. In the current study the relationships of the constructs are examined at the time when the traditional practices of doing work are changing and people are focusing on themselves as compared to considering their organizations the first priority.

It is noted from the results that the relationship of training, empowerment and rewards is weak with the performance of employees. This is due to the fact that the employees are functioning in a different environmental context at present. The training, empowerment and rewards are among the first six top most preferred HR practices rather high performance work practices that contribute positively towards employee performance (Boselie, et al., 2005; Karatepe, 2013).

Universities are the places creating and disseminating knowledge. The people working in the universities are the knowledge distributors. The private universities restrict the people to disseminate knowledge outside of the university premises while at work (Takeuchi et al., 2007). The rewards are found to have a positive relationship with employee performance (Liu, \& Li, 2017; Allen, \& Kilmann, 2001; Liu, Zhao, \& Xie, 2016; Garen, 2016) but the need to earn more and more compel teachers to jump into the open sea that is available to them in the form of freelancing websites as a gift of fourth industrial revolution. Moreover despite the fact that universities provide their teachers with the relevant trainings they do not care about the universities but focus on fulfilling their own interest (Arif \& Ilyas, 2013). It is noted here that the teachers did not like to have empowerment for the reason that they were involved in doing other tasks instead of having empowerment to perform at their primary workplace (Kundu, Kumar \& Gahlawat, 2019).

The contradiction is observed in results with respect to the employees having empowerment (Sattar, Ahmad \& Hassan, 2015; Krylova et al., 2016). The empowerment extended from the university side aggravates the performance of employees instead of having positive impact. The university teachers started solving problems using other means of communication instead of using the means that are acceptable by the university. This is likely that university teachers might have developed their own websites and might have joined other work forums for assisting 
students. The statements asked in the questionnaire, "I am allowed to do almost anything to solve student problems", and "I have control over how I solve student problems", seems more evident in reducing the required levels of performance. Thus the teachers do not concentrate upon their teaching and supervising practices (Kundu, Kumar \& Gahlawat, 2019). Further the social exchange theory also suggests that the favorable factors existing in the environment push the employees to adopt certain behavior. The empowerment offered to the employees pushes them to cross the university boundaries in offering their services (Karatepe, 2013; Cropanzano \& Mitchell, 2005).

\section{CONCLUSIONS}

The research in Employee Review, "Educational Employee in workplace challenges", elaborates that there needs a new innovation in educational sector when it comes to enhance their employee performance (Bamber, Bartram, \& Stanton, 2017). The weaker relationship of HR practices with employee performance highlight the need that the university managers must focus on providing such rewards to the employees that comple them to work only for the university in which they are working and avoid working for others. Hence the employee has to be innovative and should able to accept challenge in order to perform well when it comes to adjustment with reference to fourth industrial context.

Training regarding use of organizational resources is an important area to consider for managers. Empowerment towards doing job is another area that needs attention. By using this as a strategy people will get involved in work and can avoid indulging in unwanted affairs. Similarly the rewards helps developing commitment to the organization and people feel obliged and thus try to return to their organization in terms of better performance. It is likely that people, instead of using training as a positive tool may use it for their personal purposes. The skills learned may be used for earning more instead of using it for the university purposes.

There is a weak relationship of HR Practices with employee performance in the fourth industrial revolution context. The performance is weak because people are involved in doing extra work that is not related to their original workplace rather they are involved in doing work for others (outside of the universities they are actually teaching). The result suggests that there is a contradictory result on employee performance when it comes to educational sector. Although rewards are used to enhance employee performance so is for the training but for educational sector the result is not much positive. Empowering university teachers is not desirable.

\section{RECOMMENDATIONS}

A small from university teachers was selected for the study as a part of services 
providing organization. The sample may be extended to other sectors for examining the similar linkages. The use of questionnaire may limit study to using one way of data collection; it is recommended that the multiple sources of data collection may restrict common method bias to generate. Additionally the inclusion of other HR related variables such as employee involvement, supervisors trust and organizational commitment may also add value to the existing framework to examine under fourth industrial revolution context. Moreover examining the difference between male and female regarding the model tested will also be an interesting insight.

\section{REFERENCES}

Alam, M. (2012). Assessment of Oral Skills Development among the Students of Master in Education in the Public Sector. Sarghoda: University of Sarghoda.

Alam, Q., \& Uddin, A. B. (2013). Improving English Oral Communication Skills of Pakistani Public School's Students . International Journal of English Language Teaching, 1(2), 17-36.

Alonso, R. A. (2013). Teaching Speaking: An Exploratory Study in Two Academic Contexts. Porta Linguarum, 22, 145-160.

Ashton, P. T. (1990). Editorial. Journal of Teacher Education, 42(1), 2.

Begum, A. D. (2002). Measuring socio-economic. In A. D. Begum, Measuring socio-economic gender inequality in: Towards an alternative to the UNDP gender-related development index. (p. 251: 30.). The Hague: Instt. of Social Studies.

Brookhart, B. A., \& Freeman, D. J. (1992). Characteristics of entering teacher candidates. Review of Educational Research, 62(1), 37-60.

Brown, G., \& Yule, G. (1999). Teaching the Spoken Language. Cambridge : Cambridge University Press.

Burns, A., \& Joyce, H. (1997). Focus on Speaking. Sydney: National center for English Language Teaching and Research.

Canale, M., \& Swain, M. (1980). Theoretical Bases of Communicative Approaches to Second Language Teaching and Testing. Applied Linguistics, 1- 47.

Chomsky, N. (1965). Aspects of the Theory of Syntax. MIT Press.

Clark, C. M. (1988). Asking the right questions about teacher preparation: Contributions of research on teaching thinking. Educational Researcher, 17(2), 5-12.

Clark, C., \& Peterson, P. (1986). Teachers' thought processes. In M. Wiltrock, Handbook of Research on Teaching (3rd ed., pp. 255-296.). New York: Macmillan.

Clark, S. C. ( (2000).). Work/family border theory: A new theory of work/family balance. Human Relations, 53, , 747-770.

Creswell, J. W. (2011). Educational Research planning, conducting, and evaluating quantitative and qualitative research. Pearson.

Dawes, L. (2005). Speaking, Listening and Thinking with Computers. In E. Grugeon, L. Dawes, C. Smith, \& L. Hubbard, Teaching Speaking \& Listening in the Primary School. David Fulton.

De Souza, C. (1963). "The call of working Mother. Social Action, ", 640-646. 
Démuth, A. (2013). Perception Theories. Trnava.: Faculty of Philosophy.

Desai, V. (1967). Social Aspects of Savings, . .Bombay: : Popular Prctka;han.

Diener, E. S. ((1999). Subjective well-being: Three decades of progress. . Psychological Bulletin, , 125, 276-302.

Esmail, A., Ahmed, M., \& Noreen, S. (2015). Why Do Pakistani Students are Reluctant to Speak English. Academic Research International, 6(3), 372-383.

Farooq, M. U. (2015). Creating a Communicative Language Teaching Environment for Improving Students' Communicative Competence at EFL/EAP University Level. International Education Studies, 8(4), 179-191.

Francis, J. J. (2004). Constructing Questionnaires Based On The Theory Of Planned Behaviour A Manual For Health Services Researchers. . University Of Newcastle,C.

Frone, M. R. ((1992) ). 'Antecedents and outcomes of work-family conflict: Testing a model of work-family interface'.. Journal of Applied Psychology, 77 (1), : 65-78.

Greenhaus, J. H. ( (1985)). 'Sources of conflict between work and family roles'. Academy of Management Review, 10 (1): , 76-88.

Grugeon, E., Hubbard, L., Smith, C., \& Dawes, L. (2005). Teaching Speaking and Listening in the Primary School. Routledge.

Guest, D. ). ((2002). 'Perspectives on the study of work-life balance',,. Social ScienceInformation, 41(2), 255-79.

Halliday. (1975). Learning how to mean . Oxford University press.

Harb, J., Bakar, N. A., \& Krish, P. (2013). Instructors' and Students' Perceptions Towards using Technology in Teaching and Learning Listening and Speaking at Jordanian Universities. Interdisciplinary Journal of Contemporary Research in Business, 4(9), 1027-1041.

Harmer, J. (2001). The Practice of English Language Teaching. Edinburgh: Pearson Education limited.

Hochschild, A. ,. (1997). The Time Bind: When Work Becomes Home and Home Becomes Work. New York:: Metropolitan Books.

Hom, P.W., and Kinicki, A.J.,. (2001). "Toward a greater understanding of how dissatisfaction drives, employee turnover",. The Academy of Management Journal, Volume No.44(5),, , pp.975- 987.

Hymes, D. (1972). On communicative competence. In J. B. Pride, \& J. Holmes, Sociolinguistics: selected readings (pp. 269-293). Harmondsworth: Penguin.

Jabeen, A. (2015). The Role of Error Analysis in Teaching and Learning of Second and Foreign Language. Education and Linguistics Research, 1(2), 52-61.

Jabeen, I. (2013). English Language Teaching Implementing Collaborative Language Learning ApproachIn Federal Colleges of Pakistan. (Pakistan Research Repository) Retrieved from Pakistan Research Repository.

Jenkins, J. (2003). World Englishes. Routledge.

Kachru, B. B. (1985). Standards, codification, and sociolinguistic realism: The English language in the outer circle. In R. Quirk, \& ELG.Widdowson (Eds.), English in the World: Teaching and Learning the language and the literature (pp. 11-30). Cambridge : Cambridge University Press.

Kagan, D. (1992). Implications of research on teacher beliefs. Educational Psychologist, 27(1), 65-90. 
Kayi, H. (2006, November). Teaching Speaking: Activities to Promote Speaking in a Second Language. The Internet TESL Journal. Retrieved from The Internet TESL Journal

Kirchmeyer, C. .. ((2000)). In C. \&. (Eds.), Work-life initiatives: (pp. pp. 79-93).). West Sussex,UK: Wiley: ,Trends in organizational behavior.

Kofodimos, J. R. ((1993). Balancing act. . San Francisco: : Jossey-Bass.

Lightbown, P. M., \& Spada, N. (2006). How languages are learned (3rd ed.). Oxford University Press.

Mahmood, A., \& Ghani, M. (2012). Communicative Skills of Student Teachers in Pakistan. International Journal of Research in Linguistics and Social \& Applied Sciences, 1, 74-89.

Malik, Z. A. (2008). Discovering identities of teachers of English in Pakistan. Discovering identities of teachers of English in Pakistan. Aga Khan University, Karachi, Pakistan.

Manan, S. A., David, M. K., \& Dumanig, F. P. (2016). Language management: a snapshot of governmentality within the private schools in Quetta, Pakistan. Language policy, 15(1), 3-26.

Manan, S. A., Dumanig, F. P., \& David, M. K. (2015). The English-medium fever in Pakistan: analyzing policy,perceptions and practices through additive bi/multilingual education lens. International Journal of Bilingual Education and Bilingualism, 1-17.

Mani, v. (2013). Work Life Balance and Women Professionals. Global Journal of Managemen tand Business Research Interdisciplinary ; $13(5$.

Mark Tausig and RudyFenwic. (2001). "Unbinding Time: Alternate Work Schedules WorkLife Balance”. , Journal of Family and Economic Issues, Volume No.22(2), Human Sciences Press, , pp.101-119.

McLeod, S. (2007). Visual Perception Theory. Retrieved from SImply Psychology: www.simplypsychology.org/perception-theories.html

Nawab, A. (2012). Is it the way to teach language the way we teach language? English language teaching in rural Pakistan. Academic Research International, 2(2), 696-705.

Neetu, 1. ((2009)). Social Justice \& Empowerment.

Netemeyer, R. B. ( (1996) ). 'Ddevelopment and validation of work - family conflict and family - work conflict scales'. . Journal of Applied Psychology, 81(4). , : 400-410.

Nunan, D. (2003). Practical English Language Teaching. McGraw-Hill Education.

Nye, F.I.Hoffman,L.W. (1963). "the employed Women in America". Chigago: Rand Mcmally and comoany.

Osborn, M. M., Pearson, J. C., \& Morreale, S. P. (2000). Why Communication is Important: A Rationale for the Centrality of the Study of Communication. Journal of the Association for Communication Administration, 29(1), 1-25.

Patil, Z. N. (2008). Rethinking the Objectives of Teaching English in Asia. Asian EFL Journal, 10(4), 227-240.

Paulston, C. B. (1992). Linguistic and Communicative Competence: Topics in ESL. Multilingual Matters.

Perez-Gore, I., McCormick, R., Burton, S., \& Siddique, M. A. (2011). Perceptions of English Language Learning and Teaching Among Primary and Secondary School Teachers and Students Participating in English in Action. Dhaka, Bangladesh: English in Action (EIA). 
Perlow.L.A. (1995). Putting the work back into work/family. Group and Organization Management, ,, 20(2): 227-39.

Pietromonaco, Paula.R. (1986). " Psychological consequences of Multilpe social Roles.". psychology of Women Quarterly,vol 10.

Polit, D. F., \&. Hungler, B. P. ((1999).). Nursing Research: Principles and Method. . Lippincott(6 ed.).

Pramanik, R. (2011). Information and Communication Technology (ICT) among School-going Children.

Rahman, T. (2006). Language policy, multilingualism and language vitality in Pakistan. Trends in Liguistics Studies and Monographs, 175, 73-106.

Richards, J. C., \& Rodgers, T. S. (1986). Approaches and Methods in Language Teaching. Cambridge University Press.

Richards, J. C., \& Schmidt, R. (2010). Longman Dictionary of Language Teaching and Applied Linguistics. pearson.

Rickheit, G., Strohner, H., \& Vorwerg, C. (2008). The concept of communicative competence. In G. Rickheit, \& H. Strohner, Handbook of Communication Competence :Volume 1 of Handbooks of applied linguistics (pp. 15-62). Walter de Gruyter.

Sarfraz, S., Mansoor, Z., \& Tariq, R. (2015). Teachers' and students' perceptions of the communicative language teaching methodology in the CALL environment: A case study. Procedia - Social and Behavioral Sciences, 199, 730-736.

Savignon, S. J., \& Wang, C. (2003). Communicative language teaching in EFL contexts:Learner attitudes and perceptions. IRAL, 223-249.

Seth, M. .. (1995). Women's Development: Indian Initiatives. KURUKSHETRA-NEW DELHI$,, 43,33-35$.

Shamim, F. (2008). Trends, issues and challenges in English language education in Pakistan. Asia Pacific Journal of Education, 235-249.

Singh, K. (1972). " career and family .women's two roles.". Indian journal of social work ,Bombay.

Sinha, P. (1976). "Role conflict among Working Women,". New Delhi: Janaki Prakashan.

Smith, C. (2005). Developing Children's Oral Skills at Key Stage 2. In E. Grugeon, L. Dawes, C. Smith, \& L. Hubbard, Teaching Speaking \& Listening in the Primary School. David Fulton Publishers Ltd.

Spitzberg, B. H., \& Cupach, W. R. (1984). Interpersonal Communication Competence. SAGE Publications.

Tariq, A. R., Bilal, H. A., Sandhu, M. A., Iqbal, A., \& Hayat, U. (2013). Difficulties in Learning ENglish as a Second Language in Rural Areas of Pakistan. Academic Research International, 4(6).

Warsi, J. (2004). Conditions under which English is taught in Pakistan : an applied linguistic perspective. SARID Journal, 1(1), 1-9.

Wegerif, R., Mercer, N., \& Dawes, L. (1999, Febuary). Children's Talk and the Development of Reasoning in the Classroom. British Educational Research Journal.

Zeeshan, M. (2016). Pakistani Government Secondary Schools Students' Attitudes towards Communicative Language Teaching and Grammar Translation in Quetta, Balochistan. English Language Teaching, 9(3), 258-270. 